\title{
A Study of Modality System in Chinese-English Legal Translation from the Perspective of $\mathrm{SFG}^{*}$
}

\author{
Zhangjun Lian \\ School of Foreign Languages, Southwest University, Chongqing, China \\ Ting Jiang \\ School of Foreign Languages, Chongqing University, Chongqing, China
}

\begin{abstract}
As a special genre, legislative discourse reflects the power of a state through the usage of unusual forms of expressions in choosing words and making sentences. Based on the theory of modality in Systemic Functional Grammar (SFG) and the theory of legislative language in forensic linguistics, this study is designed to analyze the modality system in English translation of Chinese legislative discourses in its attempt to explore its translation problems. Through qualitative and quantitative analyses with the aid of Parallel Corpus of China's Legal Documents, it is found that there are three prominent anomic features in English translation of modality system in Chinese legislative discourses. These features reveal that translators of Chinese legislative discourse pursue language diversity at the cost of accuracy and authority of the law. A summary of some tactics and suggestions are also presented to deal with the translation of modality system in Chinese legislative discourses from Chinese into English.
\end{abstract}

Index Terms - modality system, Chinese legislative discourses, Systemic Functional Grammar (SFG)

\section{INTRODUCTION}

Translation of Chinese laws and regulations is an important component of international exchange of Chinese legal culture. Based on the theoretical ideas of functional linguistics, translation is not only a pure interlingual conversion activity, but, more important, "a communicative process which takes place within a social context" (Hatim \& Mason, 2002, p. 3). The legislative languages involve a large number of declarative sentences with modal expressions in which government directives, behavior standards, rights and obligations are conveyed.

What are rules and features of English translation of modality system in Chinese legislative discourses? Whether translators have functionally and adequately conveyed the communicative functions of Chinese legislative discourses with the aim of ensuring the accuracy and authority of the law? Is there any anomie phenomenon in English translation of modal operators in Chinese legislative discourses? In order to answer these questions, this study concentrates on English translation of modal operators used in Chinese legislative discourses, and attempts to explore its anomie translation features and make suggestions for the purpose of promoting legal translation in China.

\section{AN OVERVIEW OF TRANSLATION STUDY OF CHINESE LEgal LANGUAGE}

Legal language, a legal genre with authority and binding force, is different from the general language (Du, 2004, $\mathrm{p}$. 1). As a core part of legal language, legislative language is the legal document established in written form with the aim of reflecting national right and will through language. With the increase of international exchanges, translation of Chinese laws and regulations has become a key part of Chinese foreign trade and exchange. Researches on this issue are widely discussed by domestic scholars, including legal translation problems and their solutions (Du, Zhang, \& Yuan, 2004; Jin, 2009; Jin \& Hu, 2000), stylistic features of legal language and their translation strategies (Huang, 2002; Li, 2007; Peng \& Zhang, 2007), discussion of legal translation from the perspectives of specific vocabularies and legal terms (Xiao, 2001; Xin, 2003; Xiong, 2006). Researches on translation of modality system in legal discourses have extended from qualitative studies ( $\mathrm{Li}, 2007)$ to corpus-based quantitative studies (Gao, 2010; Yang, 2008). These researches provide a wealth of information about legal translation practice.

In view of these researches, the majority of them are confined to qualitative ones lacking of convincing data support. And some studies have just discussed the core modal verbs. But there has been relatively less research focusing on other modal operators, such as modal notional verbs, modal adjectives, etc. For this reason, this study makes a corpus-based quantitative investigation into modal operators in English translation of Chinese legislative discourses based on the theory of systemic functional grammar. And it attempts to find out the translation problems and their solutions. In this study, the parallel translation corpora come from the Parallel Corpus of China's Legal Documents (hereinafter referred to as PCLLD) created by the school of foreign languages, Shaoxing University. The corpora comprise 235 legislative

\footnotetext{
${ }^{*}$ This paper is supported by the Fundamental Research Funds for the Central Universities (Project No. CQDXWL-2013-043).
} 
texts and their translation versions, including 1427777 Chinese characters and 1067798 English words (Sun \& Yang, 2009).

\section{MODALiTy SySTEM THEORY}

In Systemic Functional Linguistics, language is regarded as a meaning potential system with three metafunctions: ideational function, interpersonal function and textual function. Among them, the interpersonal function of language concerns the use of language to interact with other people, to establish and maintain relationship with them, to influence their behavior, or to express our own viewpoint on things in the world. The interpersonal function of language is realized through mood system, modality system and appraisal system. As an important component of interpersonal function, modality system not only expresses the speaker's attitudes and judgments, but also reflects the speaker's assessment of validity of the proposition. "Modality refers to the area of meaning that lies between yes and no- the intermediate ground between positive and negative polarity" (Halliday \& Matthiessen, 2008, p. 618). In theoretical framework of Systemic Functional Grammar, modality system is composed of modal operators, modal adjuncts and interpersonal metaphors. But in legislative discourses, the frequencies of modal adjuncts and interpersonal metaphors are so low that they can be excluded in the analysis. Therefore, this study focuses on translation of modal operators (including modal verbs and modal adjectival predicators) in Chinese legislative discourses. There are primarily three scales of values concerning the validity of a proposition in modality system, namely high, median and low modal value. Modal operators are used to express different degrees of probability of propositions, or different degrees of obligation of proposals. For example, high value modal operator "must" carries high obligation, median value modal operator "will" or "shall" connotes median obligation. And low value modal operator "can" or "may" show low obligation.

Modality system can be further divided into Modalization and Modulation. When modality is used to argue about the probability or frequency of propositions, it is referred to as Modalization. When modality is used to argue about the obligation or inclination of proposals, it is referred to as Modulation. The process of legislation converts faith, values and moral standards into general rules and regulations enforced by judicial system. The main purpose of analyzing the modality system in legislative discourses is to explore "people's responsibility for legal proposition and commitment to future actions" (Shi \& Xin, 2008, p. 56). In terms of context situation, the function of legislative discourses is to issue directives and impose obligations. For this reason, the study of modality system in legislative discourses focuses on the modulation in modal operators. Because of the positive and negative poles of prescribing and proscribing and the different degrees of obligation and inclination in intermediate ground, modality system is classified according to different modal assignment. Contrast between English and Chinese modal operators in this study is based on Halliday \& Matthiessen's (2008, p. 116) classification of English modal operators and Peng Xuanwei's (2000, p. 123) classification of Chinese modal operators.

\section{English Translation of Modal Operators in Chinese LeGislative Discourses: Characteristics AND PROBLEMS}

\section{A. General Characteristics of English Translation of Modal Operators in Chinese Legislative Discourses}

This study retrieves Chinese and English modal operators with different assigned value from the PLLCD. The following data in descending order of frequency are obtained (see Table 1).

TABLE 1.

\begin{tabular}{|c|c|c|c|c|c|}
\hline $\begin{array}{l}\text { Chinese Modal } \\
\text { Operator }\end{array}$ & Frequency & Percentage & $\begin{array}{l}\text { English Modal } \\
\text { Operator }\end{array}$ & Frequency & Percentage \\
\hline 应当(yīngdāng) & 6104 & $44 \%$ & shall & 15181 & $63 \%$ \\
\hline 可以(kěyǐ) & 2812 & $20.20 \%$ & may & 3764 & $16 \%$ \\
\hline 不得(bùdé) & 1713 & $12.30 \%$ & must & 1188 & $5 \%$ \\
\hline 必须(bìxū) & 1420 & $10.20 \%$ & shall not & 1014 & $4.2 \%$ \\
\hline 需要(xūyào) & 722 & $5.20 \%$ & should & 997 & $4.20 \%$ \\
\hline 禁止(jìnzhǐ) & 422 & $3 \%$ & may not & 453 & $1.9 \%$ \\
\hline 不能(bùnéng) & 332 & $2.40 \%$ & be required & 361 & $1.60 \%$ \\
\hline 可能(kěnéng) & 260 & $1.90 \%$ & can & 304 & $1.30 \%$ \\
\hline 能够(nénggòu) & 72 & $0.50 \%$ & be allowed & 216 & $0.90 \%$ \\
\hline 严禁(yánjìn) & 24 & $0.17 \%$ & need & 151 & $0.67 \%$ \\
\hline 务必(wùbì) & 4 & $0.03 \%$ & be forbidden & 119 & $0.50 \%$ \\
\hline \multirow[t]{6}{*}{ 应该(yīnggāi) } & 3 & $0.02 \%$ & must not & 83 & $0.35 \%$ \\
\hline & & & might & 28 & $0.01 \%$ \\
\hline & & & could & 21 & $0.08 \%$ \\
\hline & & & will not & 21 & $0.08 \%$ \\
\hline & & & ought & 19 & $0.08 \%$ \\
\hline & & & need not & 11 & $0.04 \%$ \\
\hline Total & 13888 & & & 23931 & \\
\hline
\end{tabular}


As presented in Table 1, there is a great difference between the usage of Chinese modal operators and that of English modal operators. The general characteristics of English translation of modal operators in Chinese legislative discourses are as follows:

Firstly, in Chinese legislative discourses the great majority of modal operators are high value modal verbs, such as “应当” (yīngdāng, should), “不得” (bùdé, forbid) and “必须” (bìxū, must), while in English translation translators tend to use median and low value modal verbs, such as "shall", "may" and "should", attempting to standardize people's behavior in a relatively gentle tone rather than in an enforced way, and to avoid "the excessive abstractions and impersonality of the laws" (Tao, 2004, p. 115).

Secondly, in English translation of Chinese legislative discourses translators tend to use passive voice of causative constructions to represent different degrees of modulation, such as "be required to", "be allowed to" and "be forbidden". The reason is that obligation or willingness can be expressed by "the extensions of predicates" ( $\mathrm{Hu}, \mathrm{Zhu}, \mathrm{Zhang}, \& \mathrm{Li}$, 2005, p. 146). These structures not only provide modulation with situational meanings under compulsory conditions, but also strengthen the law's enforcement power and its degrees of non-consultation.

Thirdly, in Chinese legislative discourses the most frequently used negative modal verb is neither “禁止” (jìnzhř, prohibit) with the strongest tone nor “严禁” (yánjìn, prohibit) with the same tone. Instead it is “不得”. While in English translation the most frequently used negative modal verb is "shall not", followed by "may not". But "must not" with the strongest tone only accounts for $0.35 \%$ of all modal verbs. The result reveals that translators try to "guide the public in a positive and motivated way, rather than a negative and passive way" (Gao, 2010, p. 73), because in legislative languages “禁止” should be considered as supplement of permission, rather than negative command.

\section{B. Salient Problems in English Translation of Modal Operators in Chinese Legislative Discourses}

In order to accurately observe the tendencies to translate the Chinese modal operators, this study firstly selects the positive and negative Chinese modal operators with high frequency of occurrences, and then retrieves their English concordance lines in PLLCD, and finally builds up a self-compiled corpus. Based on the annotation and alignment of modal operators in parallel corpora, this study retrieves these modal operators and calculates the frequency of their occurrences by using WordSmith software. Through the analysis of these Chinese modal operators and their English translation, salient problems in the English translation of these modal operators are found:

Firstly, in English translation of Chinese legislative discourses, translators excessively use the median finite modal verb "shall". As the most frequently used modal verb in legislative discourses, "shall" in conjunction with the third person indicates command, obligation, responsibility, right, privilege and promise. In Table 1, the frequency of occurrences of "shall", 15181 , accounting for $63 \%$ of all modal verbs, reveals that translator has a preference for the median modal verbs.

Through the retrieval of Chinese modal verbs and analysis of the concordance lines of these words in the selfcompiled corpus, it is found that $86 \%$ of “应当” are translated as “shall”, 34\% of “必须” and 46\% of “须” (xū, must) are translated as “shall”, while $45 \%$ of “不得” are translated as “shall not” or “no...shall”. Among the corresponding Chinese modal verbs of “shall”, the power of enforcement of “必须” and “禁止” is strongest, as “必须” in example (1) and “禁止” in example (2). The power of enforcement of “须” which is the abbreviation form of “必须” is listed in the second place. And that of “应当” or “应” is in the third place. “可以” (kěy̌, can) has almost no power of enforcement because of the permission and right to choose, as in example (3).

(1) 第二十五条在有线、无线通信中传递国家秘密的，必须采取保密措施。(保守秘密法 c062)

dì èr shí wǔ tiáo zài yǒu xiàn wú xiàn tōng xìn zhōng chuán dì guó jiā mì mì de bì xū căi qŭ băo mì cuò shī băoshǒu mì mì fã

Translation: Article 25 Transmission of state secrets through wire or wireless communications shall be protected by security measures. (Law of Keeping Confidential information c062)

(2) 禁止在荒漠草原、半荒漠草原和沙化地区砍挖灌木、药材及其他固沙植物。未经

jìn zhĭ zài huāng mò căo yuán bàn huāng mò căo yuán hé shā huà dì qū kăn wā guan mù yào cái jí qí tā gù shā zhí wù wèi jīng 县级人民政府批准，不得采集草原上的珍稀野生植物。(草原法 c025)

xiàn jí rén mín zhèng fũ pī zhǔn bù dé căi jí căo yuán shàng de zhēn xī yě sheng zhí wù căo yuán fã

Translation: Cutting or digging shrubs, medicinal herbs or other sand-fixation plants on desert or semi-desert grasslands or in arid areas shall be prohibited. (Grassland Law c025)

(3) 第二十二条省、自治区、直辖市的人民代表大会常务委员会可以根据本法

dì èr shí èr tiáo sheng zì zhì qū zhí xiá shì de rén mín dài biăo dà huì cháng wù wěi yuán huì kě yǐ gēn jù běn fã 制定实施办法。 (城市组织法 C046)

zhì ding shí shī bàn fã chéng shì zŭ zhī fã

Translation: Article 22 Measures for the implementation of this Law shall be formulated, in accordance with this Law, by the standing committees of the people's congresses of provinces, autonomous regions and municipalities directly under the Central Government. (City Organization Law C046)

In example (1) and (2), the median value modal verb "shall" is used to represent the obligation of necessity and the strongest power of enforcement of “必须” or “禁止” in original sentences. But it weakens law”s power of enforcement and its degrees of non-consultation. For this reason, the legal connotations of the original sentence should be realized by 
high value modal verb "must" which emphasizes authority of law, subjectivity of government and right of legislation. Meanwhile, in English versions of Chinese laws and regulations, such as English version of Constitution of the People's Republic of China and that of the Basic Law of the Hong Kong Special Administrative Region of the People's Republic of China, it is an existing convention that “必须” is translated as “must”. In example (3), “可以” has no power of enforcement in original sentence, bestowing on government the freedom to implement this law or not, while "shall" would excessively increase the degree of obligation of government. Consequently modal verb "may" is suitable for the translation of “可以”. From the points of existing conventions and usage collocation in laws, the main function of the median value modal verb "shall" is to compel people to do something. Therefore, "shall" should be employed to translate Chinese modal verbs with stronger power of enforcement, such as “应当”, “须”, “不得”.

There are three reasons for the phenomenon of overuse of "shall" in English translation of Chinese legislations discourses. Firstly, influenced by "the legalese jargons" (Li, 2007, p. 57), legislative discourse translators habitually put "shall" before the verb, and assume that "shall" would improve the law validity of their English translations. Secondly, it results from probability of lexical choices. Systemic Functional Linguistics claims that "a language system is inherently probabilistic in nature" (Halliday \& Matthiessen, 2008). When modal verb "shall" satisfies translator's needs, the probability of being chosen is really very high. Thirdly, translators ignore the tendency of language development. Australian scholars have already pointed out that "shall" is scarcely used in daily English, "must" is the standard modal verb which expresses legal obligation and responsibility ( $\mathrm{Li}, 2007$, p. 60). Therefore "must" is used to express the power of enforcement of the law in recently enacted laws of Anglo-American countries, while "shall" is rarely used.

Modal verb "shall" has various usages and semantic meanings, but in legislative texts it should have agreed usage and single semantic meaning in order to ensure the accuracy and consistency of legal terminologies, avoid semantic ambiguity and inconsistency of concept, judgment, reasoning and legal logic. Therefore, when the laws enforce obligation and responsibility on government, replace "shall" with "must". In example (4), this study suggests that all "shall” should be replaced with "must" which ensures the power of enforcement of laws.

(4) 保险公司注册资本最低限额必须为实缴货币资本。(保险法 c163)

băo xiăn gōng sī zhù cè zī běn zuì dī xiàn é bì xū wéi shí jiăo huò bì zī běn băo xiăn fã

Original Translation: The minimum amount of registered capital for the establishment of an insurance company shall be fully paid-up in monetary form. (Insurance Law c163)

Revision: The minimum amount of registered capital for the establishment of an insurance company must be fully paid-up in monetary form. (Insurance Law c163)

Secondly, there is a tendency to overuse a great variety of expressions to translate the same modal operator. This study retrieves the English translations of four frequently used Chinese modal verbs, and then calculates and summarizes that each of them has at least seven English expressions (see Table 2).

TABLE 2.

THE DIVERSITY OF ENGLISH TRANSLATIONS OF CHINESE MODAL OPERATORS

\begin{tabular}{|c|c|c|c|}
\hline $\begin{array}{l}\text { English Translation } \\
\text { of “可以” }\end{array}$ & $\begin{array}{l}\text { English Translation } \\
\text { of “不得” }\end{array}$ & $\begin{array}{l}\text { English Translation } \\
\text { of “必须” }\end{array}$ & $\begin{array}{l}\text { English Translation } \\
\text { of “禁止” }\end{array}$ \\
\hline $\begin{array}{l}\text { shall } \\
\text { may } \\
\text { can } \\
\text { should } \\
\text { be allowed to } \\
\text { be to } \\
\text { should } \\
\text { entitled to } \\
\text { could }\end{array}$ & $\begin{array}{l}\text { may not } \\
\text { no...may } \\
\text { shall not } \\
\text { no...shall } \\
\text { no...be permitted } \\
\text { be not allowed } \\
\text { must not } \\
\text { prohibit } \\
\text { forbidden } \\
\text { not entitled to } \\
\text { can not } \\
\text { be eligible } \\
\text { no...should }\end{array}$ & $\begin{array}{l}\text { shall } \\
\text { shall be } \\
\text { subject to } \\
\text { have to } \\
\text { be necessary } \\
\text { shall be } \\
\text { necessary } \\
\text { should } \\
\text { must }\end{array}$ & $\begin{array}{l}\text { shall be } \\
\text { prohibited } \\
\text { no...shall } \\
\text { prohibit } \\
\text { no...may } \\
\text { forbid } \\
\text { not allowed } \\
\text { ban }\end{array}$ \\
\hline
\end{tabular}

As seen from Table 2, translators often use four kinds of vocabularies or structures: modal verb (must not, may not, can not, shall not), notional verb (prohibit), modal adjective (eligible) and the predicate expansion forms (not be permitted, not be allowed, be forbidden, not be entitled to). There is a wide diversity of English translations of China modal verbs.

Moreover, translators tend to use different value-assigned English modal operators to translate the same valueassigned Chinese modal operators, with an aim of achieving the diction diversity. However, translators violate the principle of consistency, conciseness and accuracy of the laws. For instance, in example (5):

(5) 第三条进出保税区的货物、运输工具和个人携带物品, 必须经由设有海关

dì sān tiáo jìn chū băo shuì qū de huò wù yùn shū gōng jù hé gè rén xié dài wù pĭn bì xū jīng yóu shè yǒu hăi guān 机构的出入口进出, 如实向海关申报, 接受海关检查。(高桥管理办法 C007)

jī gòu de chū rù kǒu jìn chū rú shí xiàng hăi guan shēn bào jiē shòu hăi guan jiăn chá gāo qiáo guan lǐ bàn fã 
Original Translation: Article 3 Goods, means of transport, or articles entering or leaving the bonded area must go through the entrance and exit of the Customs establishments. They shall be declared at the Customs truthfully and accept the inspection of the Customs. (Gaoqiao Regulations C007)

In example (5), the high value modal operator “必须” in original sentence strictly restricts goods, means of transport and belongings which are also compelled to be declared and accept the inspection. In English translation, “必须” is translated as "must", which represents the power of enforcement and obligation of the provision. However, in the aspect of declaration and inspection, translator uses "shall" which causes reader's assumption that the provision is not a necessary obligation and it has a certain degree of freedom.

Legislative texts need rigorous, precise and formal languages to strictly restrict connotation and scope of obligation, right and behavior standard. Ambiguous diction is strictly forbidden, in case the legal loophole is exploited. Similarly, translation of legislative texts should adhere to the principle of consistency of modal diction, otherwise concept confusions of obligation and right of the laws will be caused. Finally readers' speculation on different modal operators affects the accuracy and authority of the law. Therefore, in English translation of Chinese legislative texts, language diversity should not be overemphasized. Guarantee of semantic accuracy and identity should be the primary rule. "Monotonous diction and stereotyped sentences are styles of legal instruments" (Li, 2007, p. 55). Here in example (5) high value modal verb "must" should be used to ensure the preciseness and accuracy of the law. The revision translation in example (5) is as follows:

Revision: Article 3 Goods, means of transport, or articles entering or leaving the bonded area must go through the entrance and exit of the Customs establishments. They must be declared at the Customs truthfully and accept the inspection of the Customs. (Gaoqiao Regulations C007)

Thirdly, in English translation of Chinese legislative texts translators often misuse the structure of "modal verb + expansion form", such as "shall be entitled to", "shall be permitted", etc. However, in English legislative texts the single form of modal operator is frequently used to express prohibition or obligation. As seen from Table 3, the frequency of using "shall + expansion form" is much higher than that of using "expansion form". However the frequency of "shall + expansion form" is zero through retrieving in the web-accessible Anglo-American Statute Law Database.

TABLE 3.

DISTRIBUTION OF FREQUENCY OF "SHALL+EXPANSION FORM" IN ENGLISH TRANSLATION OF CHINESE LEGISLATIVE DISCOURSES

\begin{tabular}{llll}
\hline shall+ expansion & Frequency & Expansion Form & Frequency \\
\hline shall be entitled & 104 & is entitled & 62 \\
shall be prohibited & 93 & is prohibited & 83 \\
shall be allowed & 76 & is allowed & 33 \\
shall be permitted & 63 & is permitted & 11 \\
shall be forbidden & 23 & is forbidden & 54 \\
Total & 359 & Total & 243 \\
\hline
\end{tabular}

In English translation, the combination "shall" or "should" with the structure of predicate expansion undoubtedly changes the assigned value of English modal operators which is equivalent to that of Chinese modal operators. In English translation of example (6), "be required", the high value modal operator, reveals that a receipt is indispensable to litigation document. However, the combination "shall" with "be required" weakens the power of enforcement, and implies the receipt is not indispensable. Therefore, this study suggests that "shall" should be removed.

(6) 第七十七条送达诉讼文书必须有送达回证, 由受送达人在送达

dì qī shí qī tiáo sòng dá sù sòng wén shū bì xū yǒu sòng dá huí zhèng yóu shòu sòng dá rén zài sòng dá 回证上记明收到日期，签名或者盖章。（民事诉讼法 C234）

huí zhèng shàng jì míng shōu dào rì qī qiān míng huò zhě gài zhāng mín shìsù sòng fã

Original Translation: Article 77 A receipt shall be required for every litigation document that is served and it shall bear the date of receipt noted by the signature or seal of the person on whom the document was served. (Civil Procedural Law C234)

Revision: Article 77 A receipt is required for every litigation document that is served and it shall bear the date of receipt noted by the signature or seal of the person on whom the document was served. (Civil Procedural Law C234)

Similarly, in example (7), Chinese word “准予” (zhǔnyǔ, permit), a low value modal operator, represents permission and has little power of enforcement. Hence it is appropriate to translate “准予” as "be permitted to" with the equivalent value. But the combination "shall" with "be permitted to" increases the assigned value of the English translation, and improves the power of enforcement of the enterprise. Therefore, "shall” is redundant, and it should be removed.

(7) 企业支付给职工的工资和福利费，应当报送其支付标准和所依据的文件及有

qǐ yè zhī fù gěi zhí gong de gōng zī hé fú lì fèi yīng dāng bào sòng qí zhī fù biāo zhǔn hé suǒ yī jù de wén jiàn jí yǒu

关资料，经当地税务机关审核同意后，准予列支。(外资税法实则 $\mathrm{c} 082$ )

guān zī liào jīng dāng dì shuì wù jī guan shěn hé tong yì hòu zhǔn yǔ liè zhī wài zī shuì fã shí zé

Original Translation: Salaries and wages, and benefits and allowances paid by enterprises to employees shall be permitted to be itemized as expenses following agreement by the local tax authorities after an examination and verification of the submission of wage scales and supporting documents and relevant materials. (Foreign Funds Tax Law c082) 
Revision: Salaries and wages, and benefits and allowances paid by enterprises to employees are permitted to be itemized as expenses following agreement by the local tax authorities after an examination and verification of the submission of wage scales and supporting documents and relevant materials. (Foreign Funds Tax Law c082)

\section{CONCLUSION}

From all the above, it can be drawn that there are three prominent anomie features in English translation of modal operators in Chinese legislative discourses. Firstly, translators excessively use the median finite modal operator "shall" to represent the obligation of the law. But "shall" weakens the law's power of enforcement and its degrees of nonconsultation. Secondly, translators tend to misuse different value-assigned English modal operators to express the same value-assigned Chinese modal operators, and to overuse the synonymous words with the aim of pursuing language diversity. However, these translations violate the principle of consistency, accuracy and authority of the law. Thirdly, translators misuse "shall/should + predicate expansion form" which changes the assigned value of English translations. And then confusion in understanding is caused. Thus the anomie phenomenon in English translation of modal operators in Chinese legislative discourses inevitably weakens unity, compulsoriness and authority of the law.

Based on the above analysis, translators should attach great importance to the following three aspects in English translation of Chinese legislative discourses. Firstly, the principle of legal equivalence in English translation of legal texts is the golden principle. Therefore, in cross-legal translation translators should give priority to the equivalence of legal factors. Legal culture and legal convention hidden in languages should be taken into full consideration. Secondly, adherence to the principle of consistency of legal diction is highly valued in English translation of Chinese legislative discourses. Finally, as messengers of international exchange of legal culture, translators should be aware of the development trend of legal language, intensively study diction features and conventions of legal texts, and grasp the overall functions and hidden communication goals of legal texts.

\section{REFERENCES}

[1] Du, J. B. (2004). Forensic Linguistics. Shanghai: Shanghai Foreign Language Education Press.

[2] Du, J. B. Zhang, F., \& Yuan, L. (2004). Problem in Chinese legal translation and its solution. Chinese Translators Journal, 3, $72-76$.

[3] Gao, L. J. (2010). A Corpus-based analysis of key modal verbs in legal texts. Journal of Shaoxing University, 2, 69-73.

[4] Halliday, M. A. K., \& Matthiessen, C. (2008). An Introduction to Functional Grammar (3rd ed.). Beijing: Foreign Language Teaching and Research Press.

[5] Hatim, Basil, \& Mason, Ian. (2002). Discourse and the Translator. London: Longman.

[6] Hu, Z. L., Zhu, Y. S., Zhang, D. L., \& Li, Z. Z. (2005). An introduction to systemic functional linguistics. Beijing: Peking University Press.

[7] Huang, W. (2002). On translators' creativity in legal translation. Chinese Translators Journal, 2, 41-43.

[8] Jin, C. W., \& Hu, A. P. (2000). A study of existing problems in legal translation. Chinese Translators Journal, 3, 45-50.

[9] Jin, C. W. (2009). On formal equivalence in legal translation. Chinese Translators Journal, 2, 62-67.

[10] Li, K. X. (2010). On static equivalence in translating legal texts. Foreign Language Teaching and Research, 1, 59-65.

[11] Li, K. X. (2007). Functions of modal verbs in legal documents and their translation. Chinese Translators Journal, 6, 54-60.

[12] Peng, X. B., \& Zhang, X. H. (2007). Pragmatic principle of English-Chinese legal translation. Journal of Northwest University, 2, 147-156.

[13] Peng, X. W. (2000). A comparative study of English and Chinese discourse. Shanghai: Shanghai Foreign Language Education Press.

[14] Shi, G., \& Xin, B. (2008). An analysis of the modality system in the Constitution of the United States. Foreign Language Research, 2, 55-59.

[15] Sun, H. R., \& Yang, J. D. (2009). A Parallel Corpus of China's Legal Documents. http://corpus.zscas.edu.cn/ (retrieved on June 3, 2013).

[16] Tao, B. (2004). Legal English: English-Chinese Bilingual Legal Documents. Shanghai: Fudan University Press.

[17] Xiao, Y. S. (2001). The characteristics, etymology and translation of legal terms both in English and Chinese. Chinese Translators Journal, 3, 44-47.

[18] Xin, G. (2003). Translation of titles of laws and regulations. Chinese Science \& Technology Translators Journal, 3, 25-28.

[19] Xiong, D. M. (2006). Comparison and contrast between English and Chinese person deixis in legal language. Foreign Language Education, 3, 81-86.

[20] Yang, M. (2008). A study of willingness to power of legislative discourse. Foreign Languages and Their Teaching, 4, 5-8.

Zhangjun Lian was born in Shanxi, China in 1981. He received his M.A. degree in English language and literature from Yanshan University, China in 2007.

$\mathrm{He}$ is currently a Ph.D. candidate in the School of Foreign Languages, Southwest University, Chongqing, China. His research interests include functional linguistics, translation studies and corpus linguistics. 
Ting Jiang was born in Sichuan, China in 1974. She received her M.A. degree in applied linguistics from Chongqing University, China in 2002.

She is currently an associate professor in the School of Foreign Languages, Chongqing University, Chongqing, China. She is also a $\mathrm{Ph} . \mathrm{D}$. candidate in the School of Foreign Languages, Southwest University, Chongqing, China. Her research interests include forensic linguistics, corpus linguistics and functional linguistics.

Ms. Jiang is a member of China Association of Forensic Linguistics. 